\title{
Assessing the flowability of bauxite tailings at East Weipa, Queensland
}

\author{
D.J. Williams The University of Queensland, Australia \\ G. Price Golder Associates Pty Ltd, Australia \\ H. Li Rio Tinto Alcan, Australia
}

\begin{abstract}
Given the potential for the failure of mine tailings storage facilities, and the potential devastation to downstream life and property should a failure occur, it is incumbent on the operators of mine tailings storage facilities to ensure that the tailings are deposited and contained in such a way that minimises the risk that the tailings would flow in the event of a breach of the containment structure. The paper presents the results of field and laboratory investigations to assess the potential flowability of bauxite tailings at East Weipa, Queensland.
\end{abstract}

\section{Introduction}

\subsection{Historical tailings storage facility failures}

Every year between two and five of the more than 3,500 tailings (storage facility) dams in the world experience major failures. Tailings dams are more than 10 times more likely to fail than conventional hydro or water supply dams, yet their failures are potentially more dangerous because of the toxic solids and water they potentially contain.

Based on their investigation of tailings dam failures, UNEP and ICOLD (2001) concluded that the majority of failures are associated with overtopping, due to a range of causes including failure of the dam, and loss of freeboard. There has been an increase of failures starting in the mid 1960s, which is most likely due to the larger number of tailings storage facilities (TSFs) constructed after 1960, combined with the more thorough documentation of TSF operations since then. Tailings dams constructed by the upstream method are the most susceptible to failure, although this is the oldest and by far the most commonly used construction method. It was also found that about $60 \%$ of the failures occurred for dams less than $20 \mathrm{~m}$ high. The majority of failures are associated with operating facilities, with relatively few incidents associated with inactive ones, which is not surprising given the huge volumes of water generally discharged with the tailings.

Tailings dams are designed based on regional conditions (the climate, design storm event for spillway sizing, and the design earthquake), site specific conditions (foundations and topography, and available construction materials), and the mill production schedule and tailings characteristics. Tailings dams are generally designed to retain tailings that are initially discharged as a slurry, and are operated to facilitate the separation of the tailings solids from the transporting water. Upon successful completion and rehabilitation, the dam should store essentially semi-solid tailings.

According to UNEP and ICOLD (2001), the causes of tailings dam (impoundment) failure can in many cases be attributed to lack of attention to detail. The progressive construction of TSFs can span many staff changes, and sometimes changes of mine ownership. Original design heights are often exceeded, and the characteristics of the tailings can change over time as the ore and/or processing change. Lack of storage capacity can lead to a rise in the phreatic surface within the dam, localised failures that produce dam crest settlements, and overtopping of the dam. The causes of tailings dam failure include inadequate foundations exacerbated by inadequate investigations, inadequate or failed decants, dam slope instability, dam erosion, structural inadequacies, and additional (water) loading of closed facilities.

There is also a significant number of failures for which the cause is unknown. If there is a breach of a tailings dam, there is a potential for supernatant water and fluid tailings to flow through the breach. Most of the 
situations with a potential to cause failure have already been solved by geotechnical engineering technology, indicating that a more systematic application of specialised knowledge is required for TSFs.

Rico et al. (2008) compared the occurrence of tailings dam failures in different countries, and found that the numbers in various countries are roughly in proportion to the numbers of TSFs operated in each country, although Australia accounts for less than $2 \%$ of all failures despite having a disproportionately large minerals industry. Rico et al. (2008) also refined the main causes of TSF failures; listing them in order: unusual rain, unknown causes, seismic liquefaction, management failure, structural failure, piping or seepage, overtopping, foundation failure, dam slope instability, and underground mine subsidence.

\subsection{Potential flow of tailings}

Sammarco (2006) described the potentially destructive capacity of tailings flow slides from failed TSFs. There are generally two classes of failures: (i) water flows, and (ii) tailings flow slides. Water flowing over the tailings and through a breach in the dam causes erosion and the transport of sediment, which is then deposited downstream. Water flowing through the dam causes seepage and can cause piping of susceptible dam materials, which weakens the dam and can lead to its failure. Tailings flow slides involve the fluidisation or liquefaction of the tailings as the containment fails and the tailings take in water. The force with which a tailings flow slide moves downslope is determined by the volume of flow, the moisture state and particle size distribution of the tailings, the elevation of the storage, the geometry of the breach in the dam, and the slope of the hillside downslope. The potential energy of the tailings dictates the velocity and flow out distance of the flow slide, as the energy is converted to kinetic energy.

\subsection{East Weipa bauxite tailings storage facility}

Weipa is located on the western side of Cape York Peninsula in northern Queensland, in a region containing one of the world's largest deposits of bauxite. The East Weipa bauxite tailings are produced from the initial washing of the bauxite ore to separate bauxite from inert soil, which makes up about $30 \%$ by mass of the raw ore. The tailings are contained in the East Weipa TSF, which has been constructed progressively since 1970, and now comprises three cells covering about 400 ha that will ultimately reach a height of up to $25 \mathrm{~m}$. The tailings supernatant water and rainfall runoff are inert, and a significant proportion of the water is recycled to the plant. The town of Weipa has expanded over time to now be close to the northwest corner of the TSF.

The containment walls of the East Weipa TSF are constructed using 'iron stones' (gravelly clays) and compacted coarse tailings, which comprise silty gravelly sand, with $55-90 \%$ sand, 5-40\% gravel, and $5-15 \%$ silt (GHD, 2009). The fine tailings contained behind the coarse-grained containment walls comprise gravelly sandy silt, with $20-95 \%$ silt, 5-50\% sand, and 0-10\% gravel, which classify as an 'ML' (silt of low plasticity) according to the Unified Soil Classification system. During the early stages of the operation of the East Weipa TSF, the tailings were discharged from a single pipe outlet, which resulted in the capture of tailings fines in low points within the cells and against portions of the walls, and made it difficult for upstream raising. Subsequently, the tailings have been spigoted from the perimeter walls, and the supernatant water collected from towards the centre of the entire facility.

A slumping of a section of the southwestern wall of the East Weipa TSF occurred in October 2008, as the wall was being raised. The slumping did not cause a breach of the TSF and there was no threat of the outflow of water or tailings. The slumping was associated with the capture of under-consolidated tailings fines in an early borrow pit located adjacent to and just inside the wall. The remedial action taken was to relocate the wall to the west, partially onto the firm engineered embankments.

The proximity of dwellings to the northwest of the TSF and the occurrence of the slumping prompted investigations of the stability of the walls of the TSF cells and of the flowability of the tailings. This paper addresses the second question, which was addressed by field and laboratory investigations.

\subsection{Previous relevant studies of East Weipa bauxite tailings}

Previous work by Swarbrick and Fell (1992) carried out on fine-grained East Weipa bauxite tailings indicated that their specific gravity was 2.77 . Settling and desiccation in the field of fine-grained East Weipa bauxite tailings deposited at an initial $20 \%$ solids by mass showed that a $0.3 \mathrm{~m}$ initial thickness layer took 
six days to settle, while a $1.9 \mathrm{~m}$ initial thickness layer took 69 days to settle. The maximum dry density achieved was $1.49 \mathrm{~g} / \mathrm{cm}^{3}$, at a gravimetric moisture content (= mass of water/mass of solids, expressed as a $\%$ ) of about $28 \%$ and a degree of saturation of about $95 \%$. Laboratory settling tests carried out on the finegrained tailings from an initial $20 \%$ solids by mass showed that $0.5 \mathrm{~m}, 1 \mathrm{~m}$ and $2 \mathrm{~m}$ initial thickness layers took 49 days, 90 days and 165 days to settle, respectively, much longer than in the field. The maximum dry density achieved in the laboratory tests was $1.28 \mathrm{~g} / \mathrm{cm}^{3}$, at a saturated gravimetric moisture content of about $35 \%$, achieving a peak vane shear strength of about $15 \mathrm{kPa}$.

Previous testing of East Weipa bauxite tailings carried out by GHD (2009) indicated specific gravities of 2.69 for the coarse-grained tailings and 2.77 for the fine-grained tailings, with an average value of 2.73 . The dry density achieved on settling was in the range from $1.2-1.5 \mathrm{~g} / \mathrm{cm}^{3}$, indicating a gravimetric moisture content in the range from 46-28\% for an assumed degree of saturation from 1-0.95. Measured tailings beach slopes were in the range from $0.4-2 \%\left(0.2-1.1^{\circ}\right)$, for beaches $200-600 \mathrm{~m}$ long.

\section{Details of field and laboratory investigations}

\subsection{Aim of investigations}

The aim of the field and laboratory investigations to assess the flowability of East Weipa bauxite tailings was to identify, validate and calibrate a simple index or indices to define the 'non-flowable' state of East Weipa bauxite tailings, and hence to develop appropriate operational procedures (that is, maximum deposition depth and minimum cycle time between layers) to ensure they will not be flowable.

\subsection{Possible tailings flowability indices identified initially}

Possible flowability indices identified initially included: (i) the gravimetric moisture content of the tailings being greater than their liquid limit, times some factor greater than unity; (ii) the shear stress of the tailings being greater than their yield stress, times some factor greater than unity; (iii) the yield stress versus gravimetric moisture content turning point (expected to be about $50 \mathrm{~Pa}$ ); (iv) the shear wave velocity of the tailings being greater than some value (of the order of $200 \mathrm{~m} / \mathrm{s}$ ); and (v) the slump of the tailings being less than some height. None of these indices is a direct measure of flowability, and all require validation and calibration against actual flowability performance; that is, they need to be tested in the field.

\subsection{Field trial beaches and sampling for laboratory testing}

Three field trial beaches were formed, depositing up to $0.5 \mathrm{~m}$ of fresh tailings on top of desiccated tailings on the East Weipa TSF. The open-ended Cell 2 (Figure 1) was filled from a single spigot and the beach tested in situ two days later for vane shear strength to $58 \mathrm{~m}$ down the beach and its beach profile, and sampled for laboratory gravimetric moisture content, total suction (a measure of desiccation), and particle size distribution analysis. The closed-ended Cell 9 (Figure 2) was filled from a single spigot, the supernatant water drained via a pipe, and the beach tested to the closed end at $26 \mathrm{~m}$ as for the open-ended cell, plus testing the vane shear strength of the tailings at $26 \mathrm{~m}$ over time to assess desiccation. Cells 2 and 9 were laterally-constrained. An unconstrained spigot (Figure 3) was run for four days and tested from 0.5-30 days as for the two cells, progressing further down the beach with time after deposition (to $100 \mathrm{~m}$ initially and progressively to $150 \mathrm{~m}$ ). Cell 9 represents a worst case since the fines are trapped behind the closed-end, rather than flowing freely. An assessment of tailings flowability was made by observing the stability of the walls and base of test pits dug by spade to facilitate sampling down to $0.433 \mathrm{~m}$ depth at each test location.

The vane shear strength was determined using a Geovane hand-operated field shear vane (http://www. humboldtmfg.com/c-1-p-42-id-1.html), using a vane measuring $33 \mathrm{~mm}$ in diameter by $66 \mathrm{~mm}$ long, at midvane depths of $0.033 \mathrm{~m}, 0.233 \mathrm{~m}$ and $0.433 \mathrm{~m}$. Both the peak vane shear torque on initial rotation of the vane, and the remoulded vane shear torque obtained on the remoulded surface after three full vane revolutions, were recorded. From these, the shear strength $\tau$ was obtained using the conventional equation:

$$
\mathrm{T}=\pi \cdot \tau\left(\mathrm{D}^{2} \cdot \mathrm{H} / 2+\mathrm{D}^{3} / 6\right)
$$

where $\mathrm{T}$ is the measured torque in $\mathrm{kN} . \mathrm{m}, \mathrm{D}$ is the vane diameter in $\mathrm{m}$, and $\mathrm{H}$ is the vane length in metres. The shear strength values obtained were corrected for shear on the shear vane rods, by measuring the torque 
for the rods only. The calculated shear strengths were corrected for shear on the vane rods. Note that since all of the tailings tested with the field shear vane were sandy, drainage during the course of testing is likely and the measured values are an indication of the drained shear strength of the tailings.

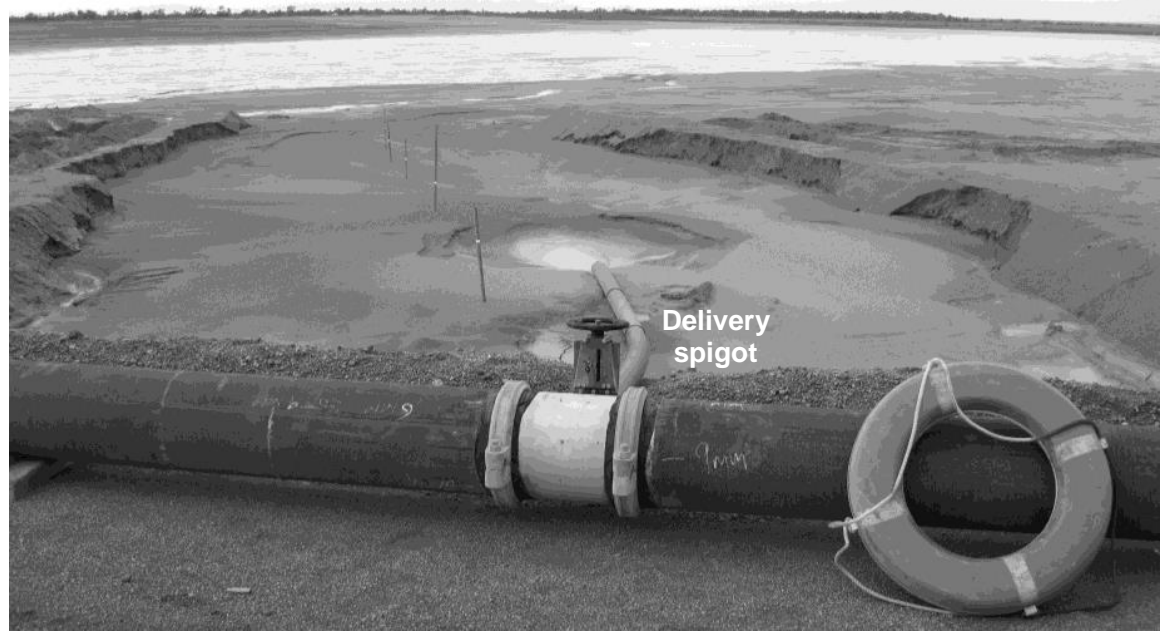

\section{Figure 1 Open-ended trial Cell 2 beach}

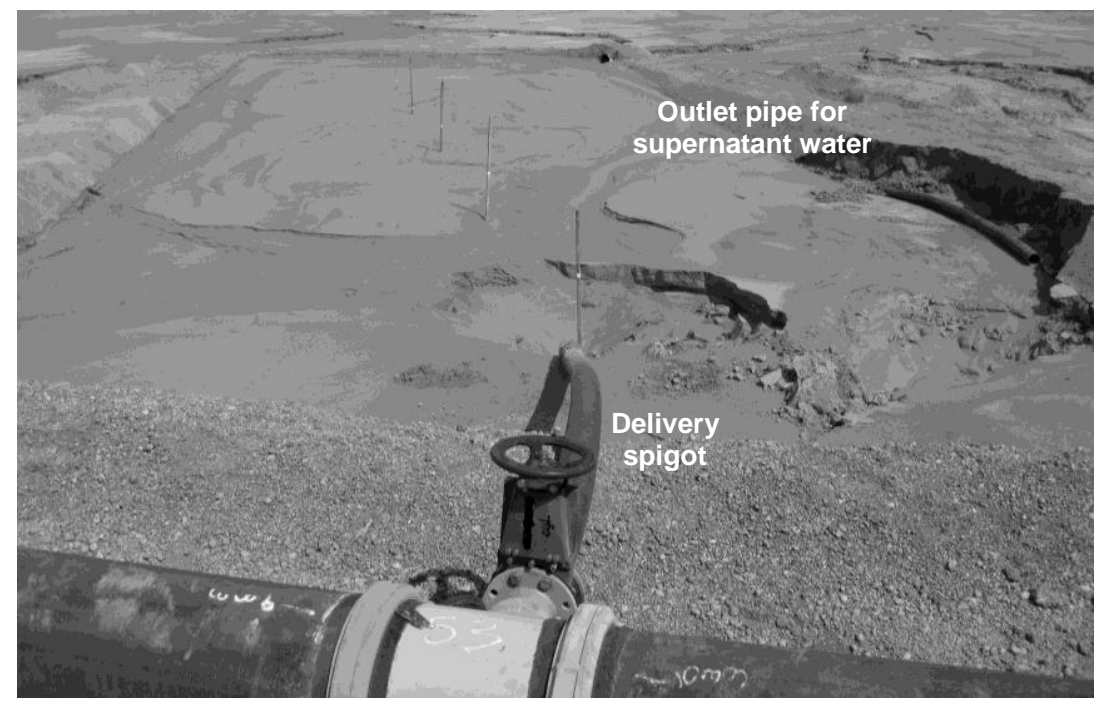

\section{Figure 2 Closed-ended trial Cell 9 beach}

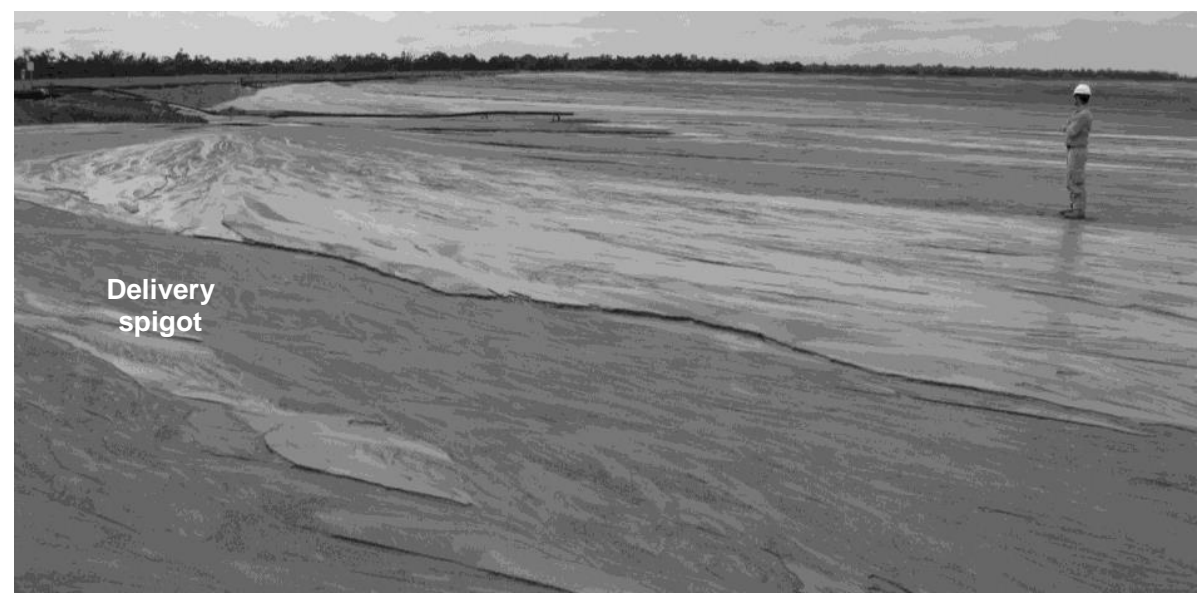

Figure 3 Trial spigot beach 
Where appropriate, the laboratory testing was carried out in accordance with AS 1289. The as-sampled moisture states of the tailings samples collected were determined in the onsite laboratory as quickly as possible after sampling to preserve their moisture. This included gravimetric moisture content determinations by oven-drying at $105^{\circ} \mathrm{C}$, and total suction determinations using a WP4 dewpoint potential meter. Since the electrical conductivity of the samples is known to be low (less than $50 \mu \mathrm{S} / \mathrm{cm}$ ), the osmotic suction would be negligible (less than $1 \mathrm{kPa}$ ), and the matric suctions would be similar to the total suctions.

Being sandy (rather than the fine-grained East Weipa bauxite tailings tested by Swarbrick and Fell (1992)), most of the tailings samples collected were non-plastic, with the exception of a sample taken from the closed-end of Cell 9 (at $26 \mathrm{~m}$ ), on which Atterberg limit testing was carried out. Again, due to the sandy nature of all of the tailings samples, sieving only down to $0.038 \mathrm{~mm}$ was carried out. In order to best represent the flocculated state of the tailings at discharge, sample preparation involved only air-drying and dry sieving.

\subsection{Other laboratory testing considered}

Other laboratory testing considered for the East Weipa bauxite tailings included consolidation testing, saturated permeability testing, soil water characteristic testing, vane shear testing versus gravimetric moisture content on settling and desiccation, slump testing versus gravimetric moisture content, rheology testing, yield stress versus gravimetric moisture content testing, and shear wave velocity testing. Due to the sandy nature of all of the tailings samples collected, consolidation testing was not appropriate, and the tailings were observed to drain rapidly on the upper beach, as evidenced by their supporting a person to a distance of about $100 \mathrm{~m}$ down the beach within half a day of the spigot being flushed with water and turned off. It was decided that the shear strength of the tailings on settling and desiccation was best assessed in the field. Again, because of the sandy nature of the tailings, slump testing and rheology testing were not considered appropriate, and since the tailings were found to be largely non-flowable their vane shear velocity would shed little light on this phenomenon.

\section{$3 \quad$ Results of field investigation}

\subsection{Average vane shear strength profiles with depth}

Figure 4 shows average vane shear strength profiles with depth in East Weipa bauxite tailings, including the average peak and remoulded vane shear (PVS and RVS) profiles in the 2 week old desiccated tailings located in the vicinity of Cells 2 and 9 tested prior to the trials, and the average profiles for 2 day old tailings in Cells 2 and 9. Also shown in Figure 4 is the estimated (based on previous measurements in similar tailings) shear strength profile due to self-weight settling of the tailings only, which increases from zero at the ground surface at a rate of $1.5 \mathrm{kPa} / \mathrm{m}$ depth, or about 0.22 times the vertical effective stress.

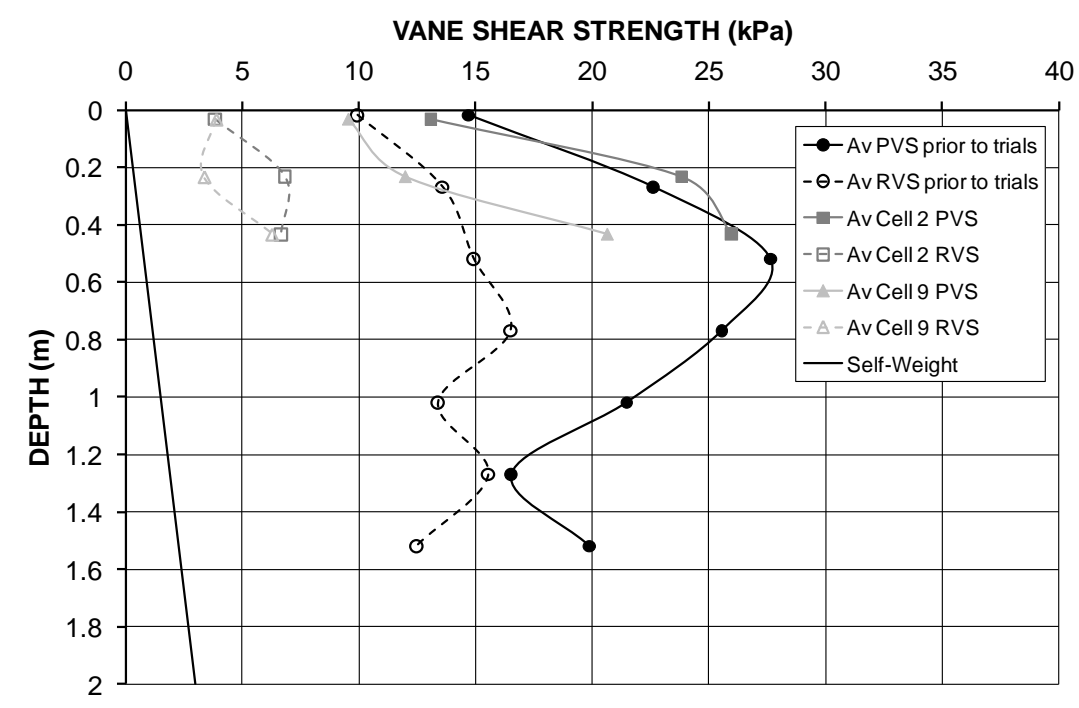

Figure 4 Average vane shear strength profiles with depth 
It is clear that all of the tailings beaches were on average well-drained and desiccated by the time of testing ( 2 days to 2 weeks old), since they all plot well to the right of the self-weight only profile. The coincidence of the average peak vane shear strength profiles for the 2 week old tailings beach and the 2 day old Cell 2 beach demonstrate little increase in strength between 2 days and 2 weeks, due to rapid drainage. However, the average peak vane shear strength of the 2 day old Cell 9 closed-ended beach is about two-thirds that of the other two, due to the capture and retention of fines, and drainage at the end of the beach being restricted.

For the 2 week old tailings beach, the average remoulded to peak vane shear strength ratio was about 0.65. For the 2 day old tailings beaches, this ratio was only $0.3-0.4$, indicating that the remoulded vane shear strength was much less well developed after 2 days than after 2 weeks.

\subsection{Vane shear strength profiles with depth for closed-ended Cell 9}

Figure 5 shows the peak and remoulded vane shear strength depth profiles with distance down the 2 day old closed-ended Cell 9 beach. The closed end is a worst case, forcing the capture of fines and restricting the drainage of the beach, which would not occur in practice. There is a very general trend of decreasing strength (both peak and remoulded) with increasing distance down the beach, as expected. Of key significance, at the closed end $(26 \mathrm{~m})$, where fines were trapped and water remained on the surface at the time of testing, the peak and remoulded vane shear strengths over the upper $0.25 \mathrm{~m}$ depth were at or below the self-weight profile. This location was the only one tested that showed the tailings to be flowable. Thus a criterion for flowability is that it occurs where the shear strength is at or below the self-weight only shear strength.

PEAK VANE SHEAR STRENGTH (kPa)

$\begin{array}{lllllllll}0 & 5 & 10 & 15 & 20 & 25 & 30 & 35 & 40\end{array}$

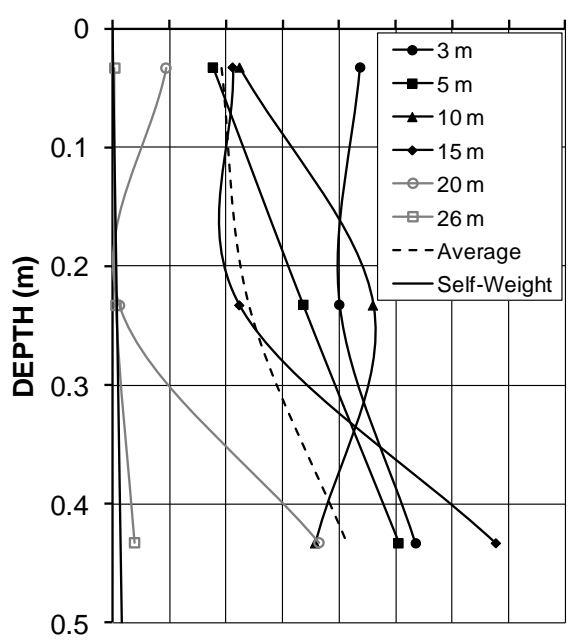

(a)
REM VANE SHEAR STRENGTH (kPa)

$\begin{array}{lllllllll}0 & 5 & 10 & 15 & 20 & 25 & 30 & 35 & 40\end{array}$

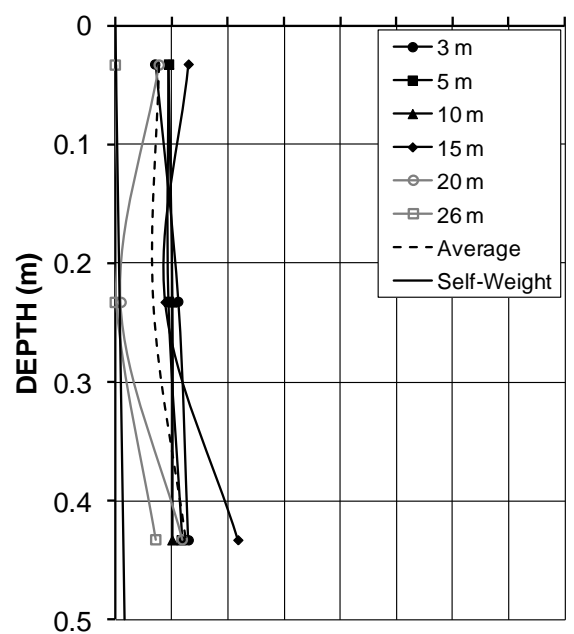

(b)

Figure 5 Closed-ended Cell 9 (a) peak and (b) remoulded vane shear strength profiles with depth

The increase in peak and remoulded vane shear strengths with time (as the tailings desiccate) for the closed end of Cell 9 at $26 \mathrm{~m}$ is shown in Figure 6. It is clear from Figure 6 that the near-surface shear strength kicked off about 5 days after deposition, while at $0.233 \mathrm{~m}$ depth this occurs more than 10 days after deposition. The increase in strength with time is clearly driven by solar-induced desiccation from the surface, rather than drainage, since the effect is very much more rapid and marked towards the surface. Despite the fine particle size distribution at this location, the near-surface peak vane shear strength rises to a high value of almost $30 \mathrm{kPa}$ at 40 days after deposition. However, the near-surface remoulded vane shear strength remains low at less than one-tenth of the peak value.

\subsection{Peak vane shear strengths for spigot beach}

Figure 7 shows a general increase in peak vane shear strength for the spigot beach, for selected distances down the beach at selected times. The recent deposition of tailings at the top of the beach $(0 \mathrm{~m})$ limits the initial near-surface strength, while at depth the tailings at this location have had a chance to settle, drain and 
consolidate to a high strength. Further down the beach (at $50 \mathrm{~m}$ and $100 \mathrm{~m}$ ), the peak vane shear strength reaches a maximum towards the surface, dramatically increasing due to desiccation with time (as seen at $100 \mathrm{~m}$ down the beach), until it approaches a maximum value at about 20 days after deposition. At depth, the increase in the peak shear strength is much less dramatic, while it also reaches a maximum value in excess of $50 \mathrm{kPa}$ at about 20 days after deposition.

Figure 8 shows that to about $50 \mathrm{~m}$ down the spigot beach, the near-surface peak vane shear strength is initially reduced due to fresh deposition near the spigot, while the strength at depth is increased by settling, drainage and consolidation. Initially, from 50-100 m down the spigot beach, the peak vane shear strength reduces down the beach. Beyond $100 \mathrm{~m}$ down the spigot beach, with time the peak vane shear strength increases, particularly near the surface due to desiccation.

\subsection{Profiles for Cells 2 and 9 and spigot beaches}

Figure 9 shows the profiles for Cells 2 and 9 and the spigot beach to natural and exaggerated vertical scales. The open-ended Cell 2 beach had an initial slope of about 5\% (or about $2.8^{\circ}$ ) dropping to about 2.5\% (or about $1.4^{\circ}$ ) from about $25 \mathrm{~m}$ down the beach. The closed-ended Cell 9 beach had an average slope of about $1 \%$ (or about $0.6^{\circ}$ ). The longer spigot beach had an average slope of about 3\% (or about $1.8^{\circ}$ ). These beach slopes apply to the upper $26-120 \mathrm{~m}$ of the beach and hence would likely over-estimate the overall average beach slope, as suggested by the beach slopes in the range from $0.4-2 \%$ for beaches $200-600 \mathrm{~m}$ long reported by GHD (2009).

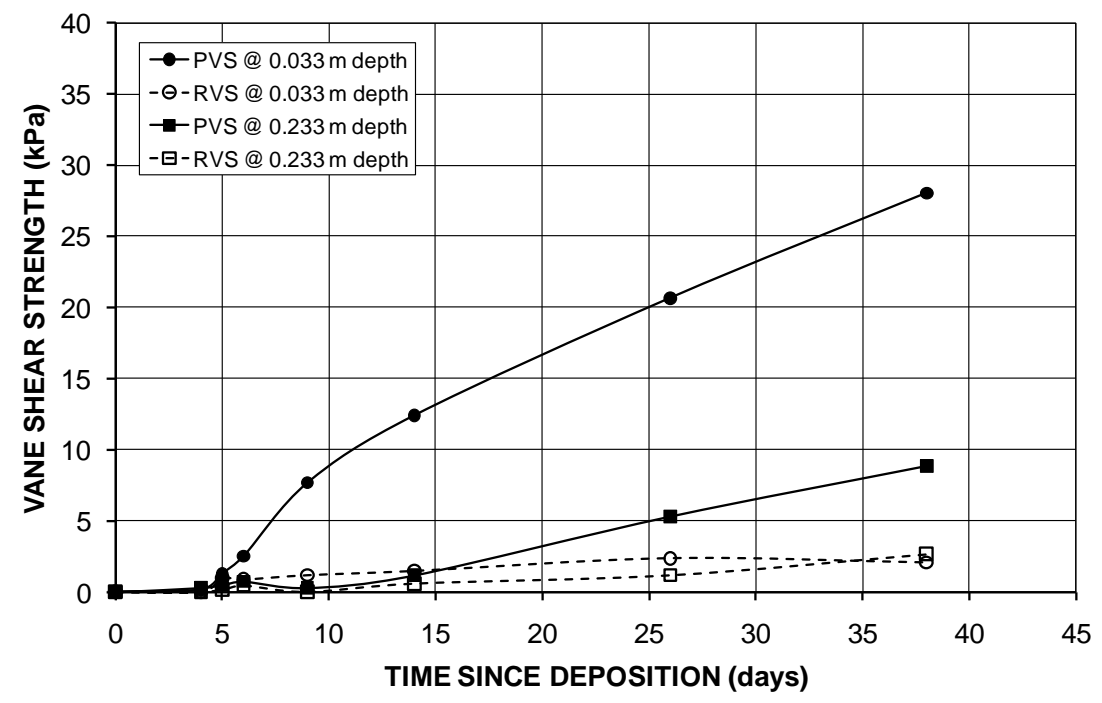

Figure 6 Increase in vane shear strengths with time for closed end of Cell 9 at 26 m 


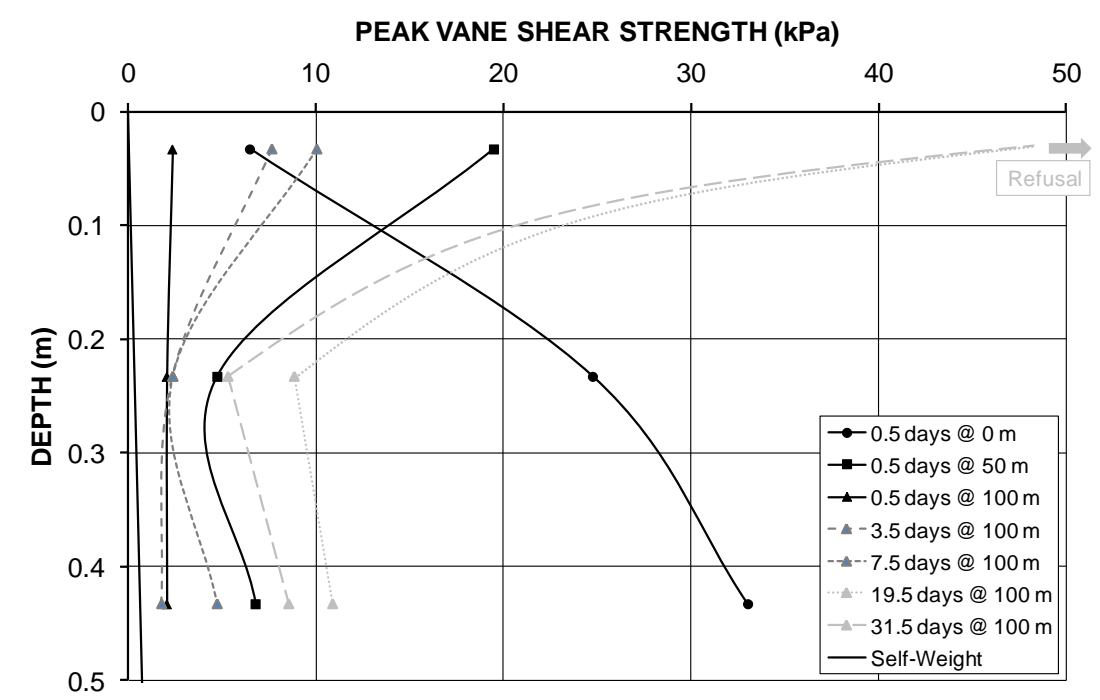

Figure 7 Increase in peak vane shear strengths for spigot beach, with distance down beach and time

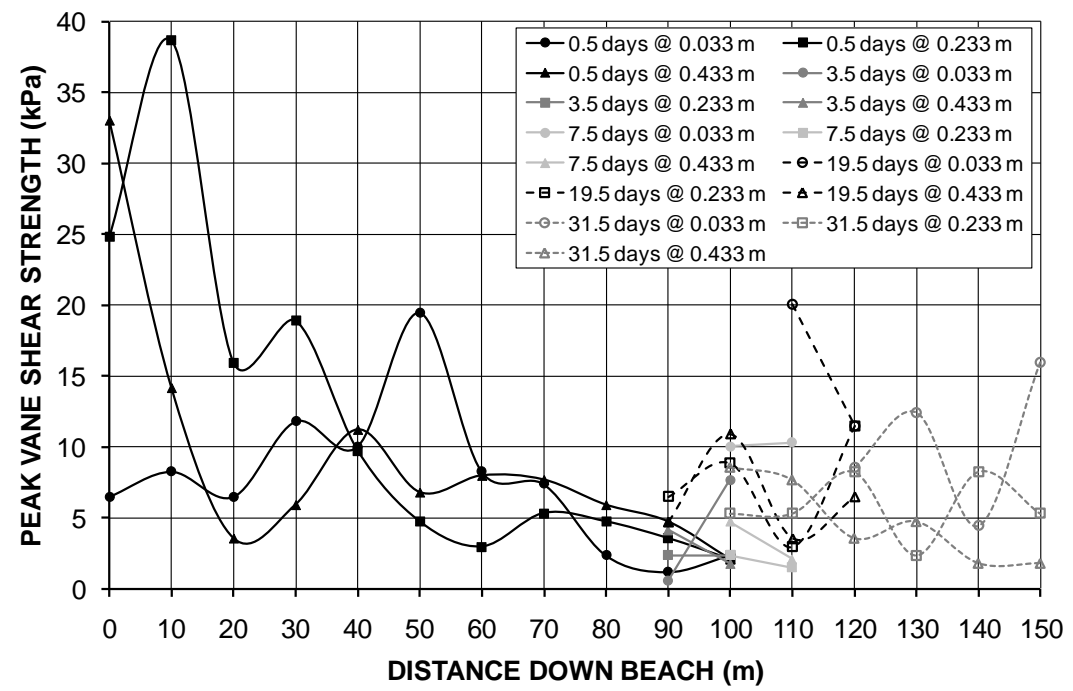

Figure 8 Increase in peak vane shear strengths along spigot beach, with depth and time 
(a)
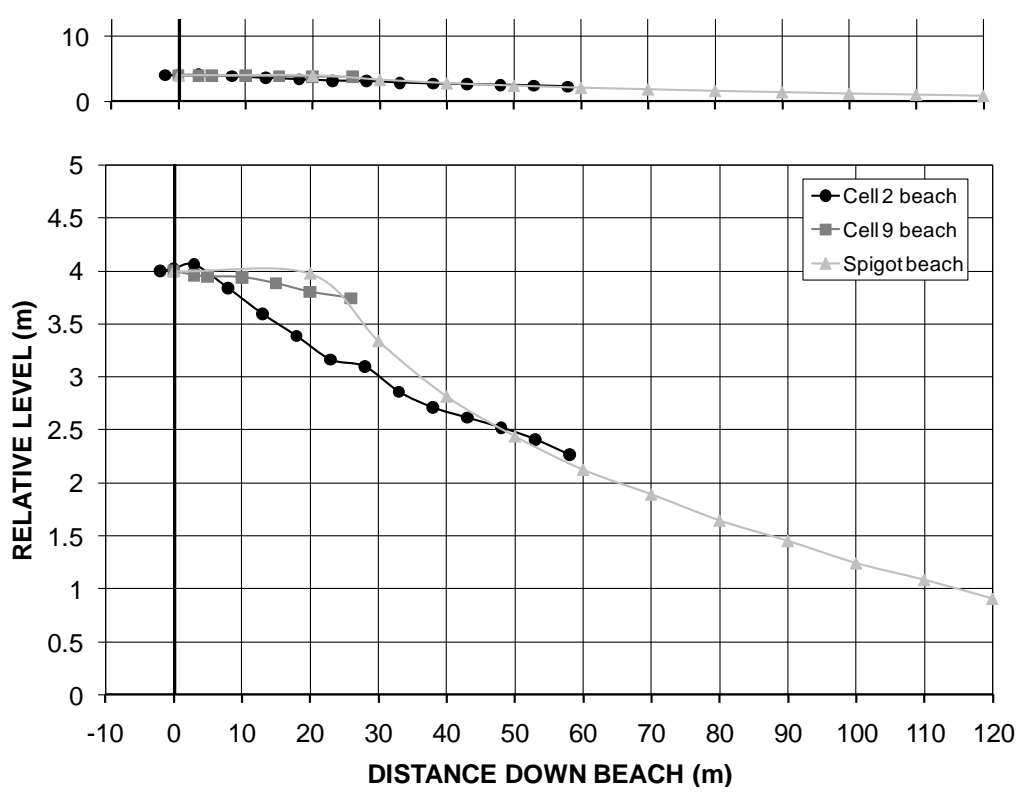

Figure 9 Beach profiles to (a) natural and (b) exaggerated vertical scales

\section{$4 \quad$ Results of laboratory investigation}

\subsection{As-sampled moisture state of tailings}

Figure 10 shows the gravimetric moisture content at $0.033 \mathrm{~m}$ depth with distance down each trial beach, with a general trend of increasing moisture content down each beach. This is expected due to the hydraulic sorting of particles down the beach, with the more free-draining coarse-grained particles dropping out towards the top of the beach and less well-draining finer-grained particles being carried further down the beach. Figure 11 shows the calculated dry density, with distance down the beach, for (assumed saturated) gravimetric moisture contents of greater than $30 \%$. The calculated dry density shows a decreasing trend down the beaches. The average calculated dry density is about $1.30 \mathrm{~g} / \mathrm{cm}^{3}$, and the maximum value is about $1.49 \mathrm{~g} / \mathrm{cm}^{3}$, similar to the values reported by Swarbrick and Fell (1992), despite their testing being on finegrained East Weipa bauxite tailings.

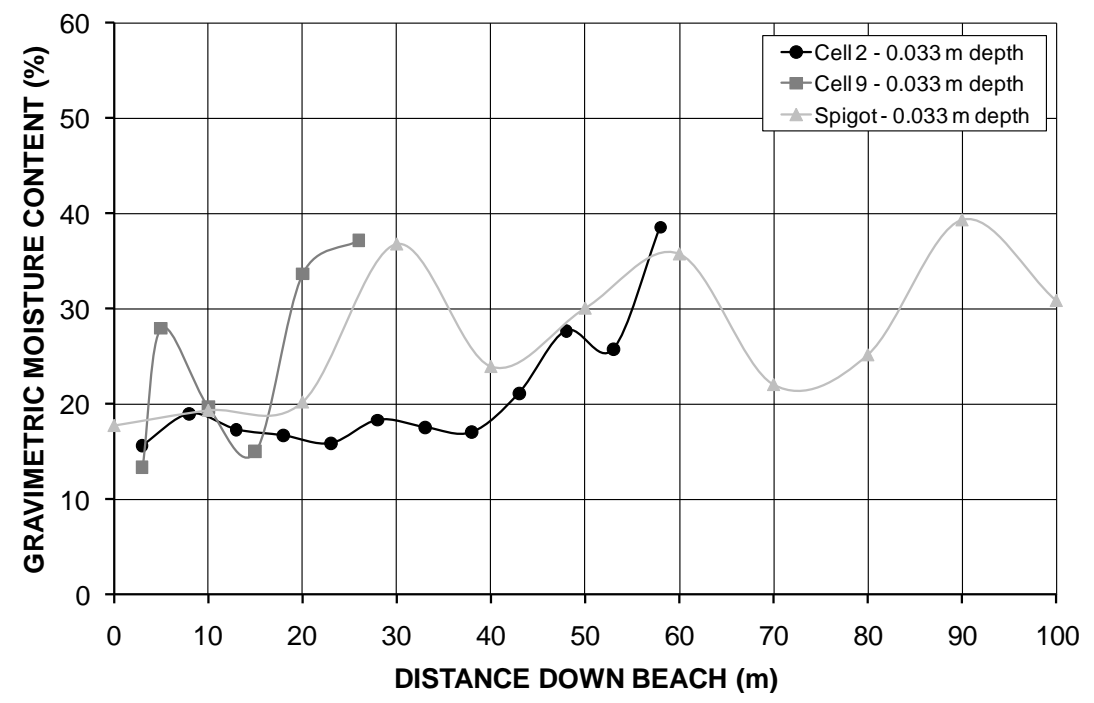

Figure 10 Gravimetric moisture content at $0.033 \mathrm{~m}$ depth, with distance down each trial beach

In general, the recovered tailings samples were non-plastic, and neither a liquid limit nor plastic limit could be obtained. Atterberg limit testing was restricted to the one fine-grained sample recovered, from the far end 
of the closed-ended trial (at a distance down the beach of $26 \mathrm{~m}$ ). A liquid limit of $35.2 \%$ and plastic limit of $25.6 \%$ were obtained for this fine-grained sample, indicating a plasticity index of $9.6 \%$, and implying a Unified Soil Classification of ML (silt of low plasticity).

Figure 12 shows the considerable scatter of the as-sampled gravimetric moisture content versus total suction data for all of the desiccated and trial beach samples collected, which is partly due to the different particle size distributions of the samples. All of the samples collected, apart from the initial samples collected from the closed end of Cell 9 at $26 \mathrm{~m}$ down the beach, recorded a finite total (and hence matric) suction in the range from $10-3,000 \mathrm{kPa}$, and hence had experienced desiccation. It is noted that the spigot beach data show the most scatter since samples were collected over time from 0.5-31.5 days after deposition, and are hence affected by increasing desiccation with time as well as different particle size distributions.

Figure 13 shows gravimetric moisture content versus total suction data at $0.033 \mathrm{~m}$ depth for all trial beaches. These data show much less scatter. They are for samples collected from near to the surface, and hence have been subjected to more desiccation, reducing the gravimetric moisture content to generally less than $40 \%$ and increasing the minimum suction to $40 \mathrm{kPa}$. However, these data are also affected by differences in the particle size distribution.

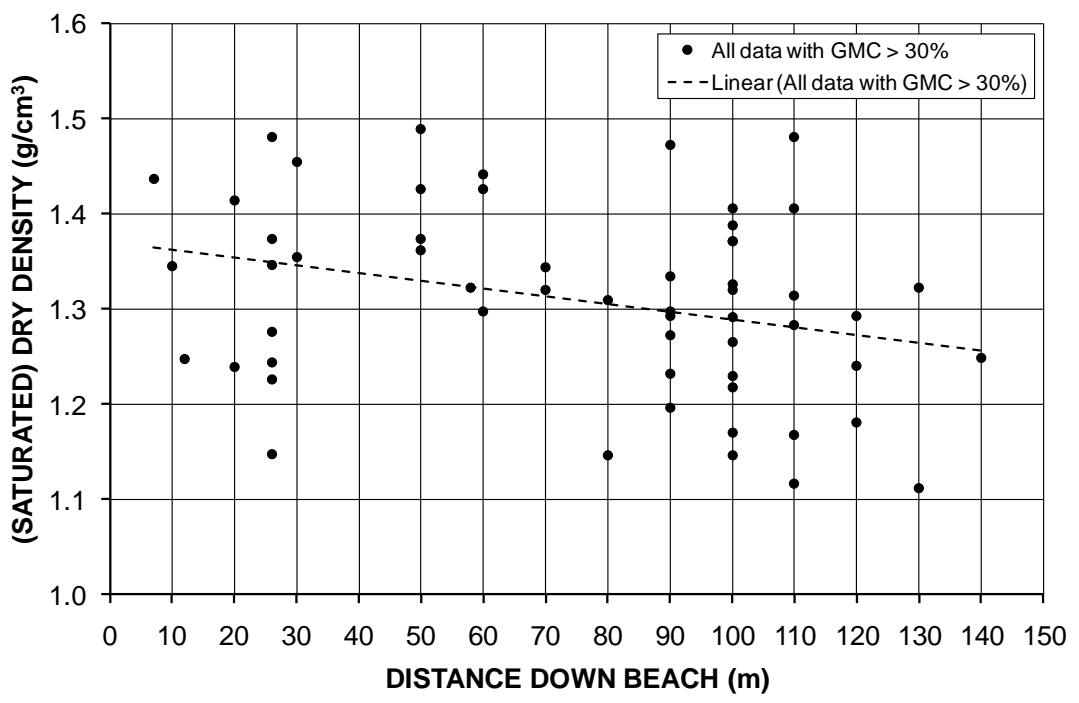

Figure 11 Calculated dry density, with distance down each trial beach, for (assumed saturated) gravimetric moisture contents of greater than $30 \%$

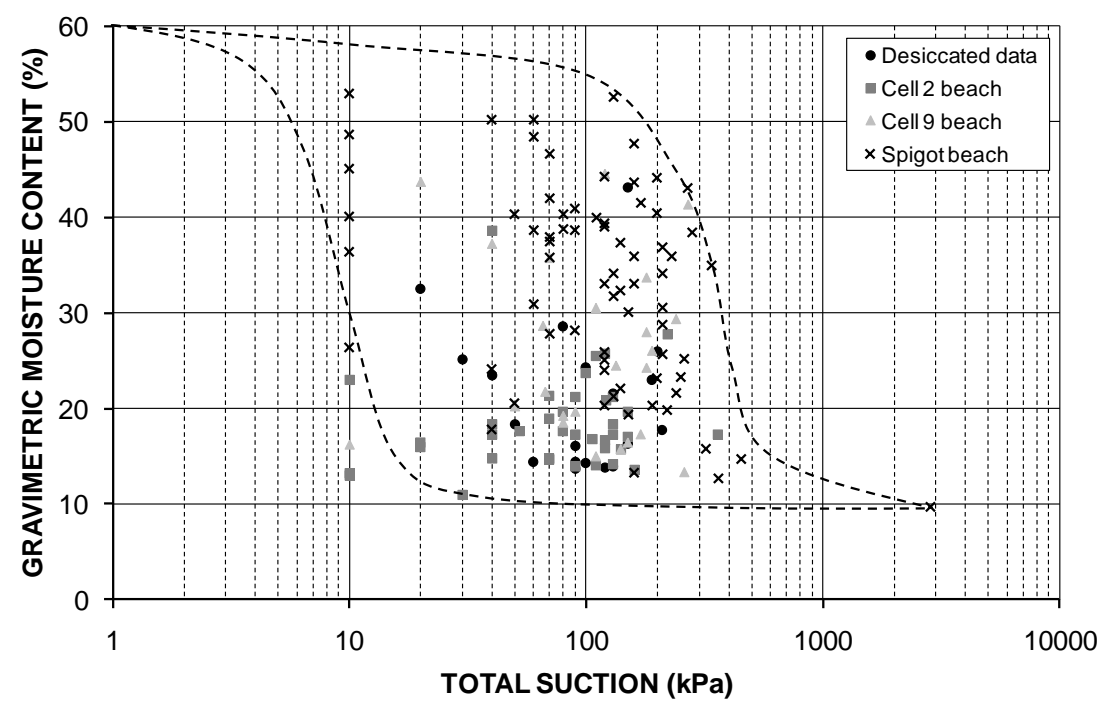

Figure 12 Gravimetric moisture content versus total suction data for all desiccated and trial beach samples collected 
Figure 14 shows gravimetric moisture content versus total suction data for samples collected between $90 \mathrm{~m}$ and $110 \mathrm{~m}$ down the spigot beach over time. Being from a similar distance down the beach, these samples had a similar particle size distribution, and hence display more consistent (particle-size independent) trend lines.

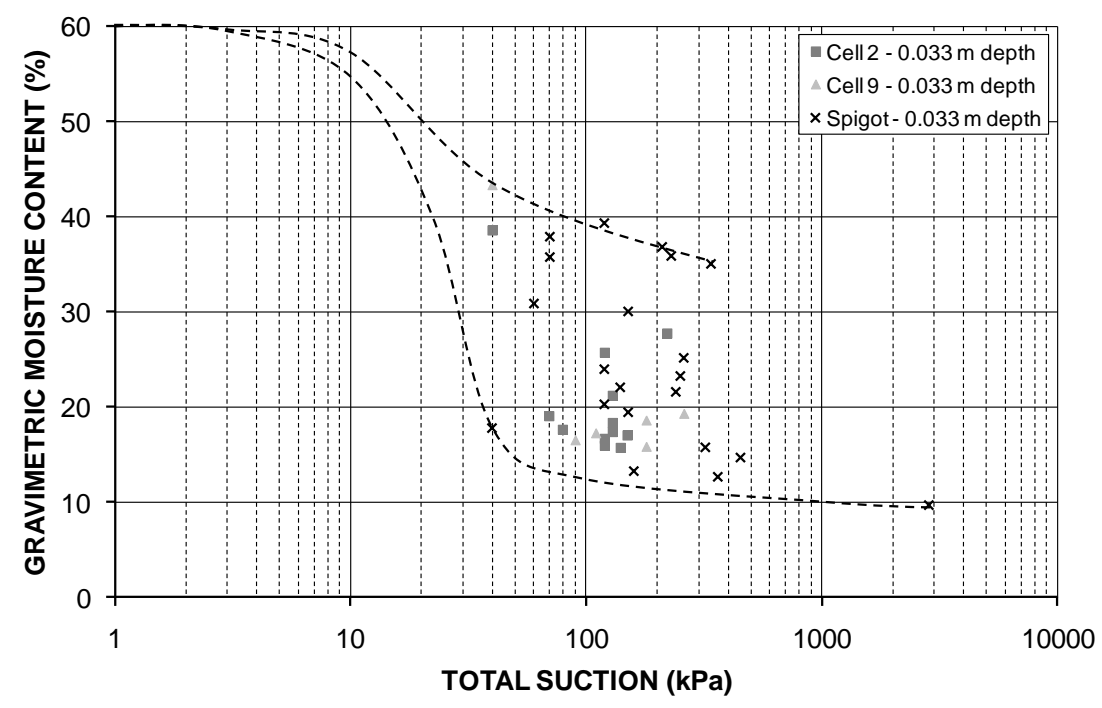

Figure 13 Gravimetric moisture content versus total suction data at $0.033 \mathrm{~m}$ depth, for all trial beaches

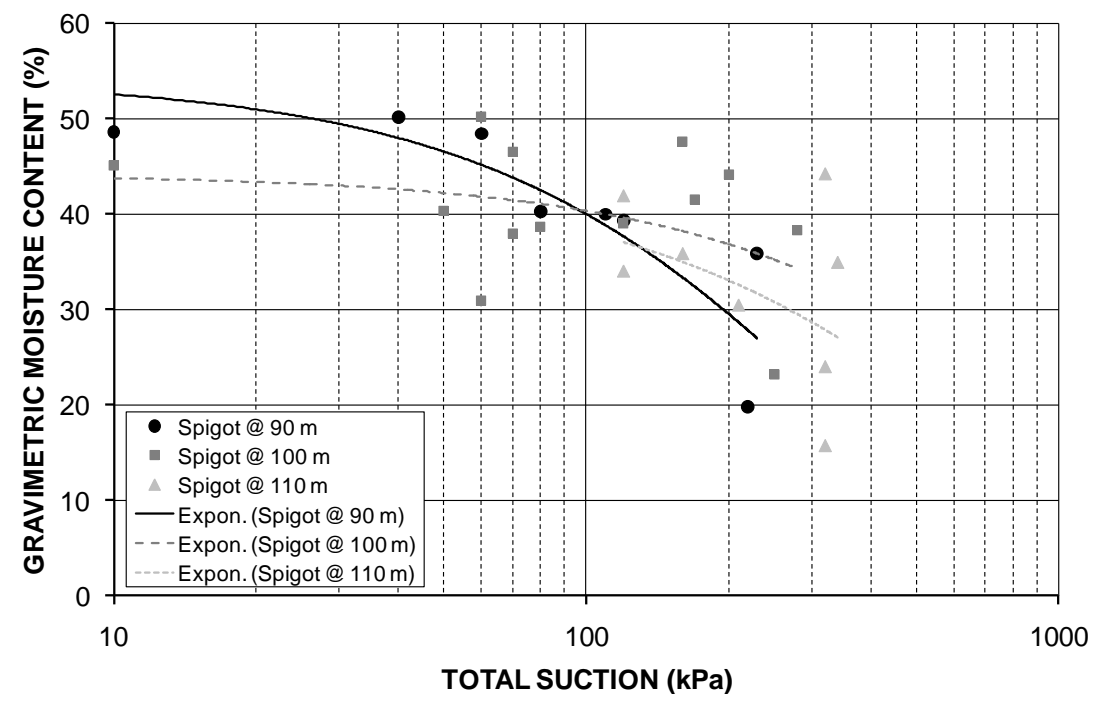

Figure 14 Gravimetric moisture content versus total suction data for spigot beach from 90-110 m

\subsection{Particle size distributions of sampled tailings}

The particle size distribution curves obtained for the near-surface tailings $(0.033 \mathrm{~m}$ depth $)$ sampled with distance down the spigot beach are shown in Figure 15 to be gravelly silty sand, with up to $13 \%$ gravel, $78-90 \%$ sand, and up to $17 \%$ silt. Cell 2 beach samples covered a similar range, while the tailings captured on the closed-ended Cell 9 beach comprised an increasing proportion of medium to fine-grained sand at the expense of gravel and coarse-grained sand towards the closed end. Figure 16 shows plots of the median particle sizes $\mathrm{D}_{50}$ of the near-surface tailings $(0.033 \mathrm{~m}$ depth $)$ sampled down each of the trial beaches. The plots are reasonably well described by exponential trend lines, with the laterally confined Cells 2 and 9 beaches showing greater hydraulic sorting of particles than the spigot beach. 


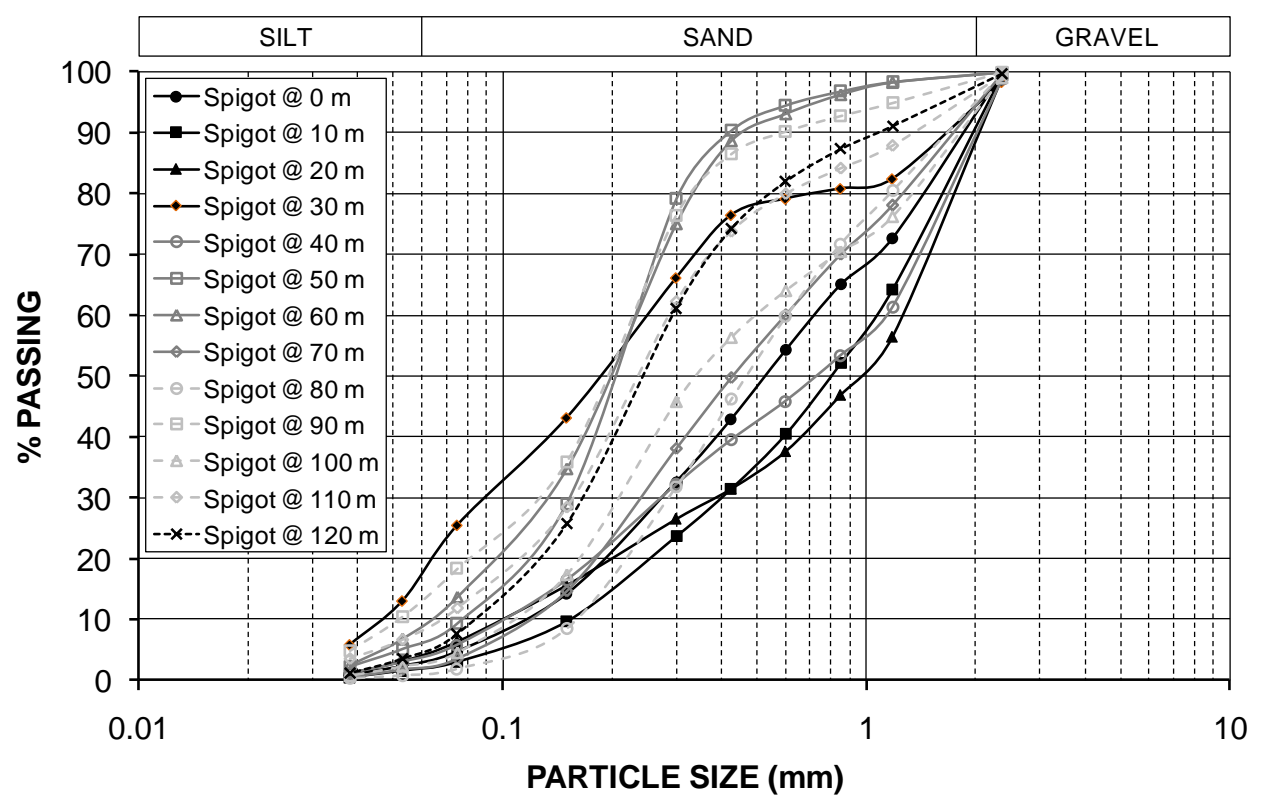

Figure 15 Particle size distribution curves for near-surface $(0.033 \mathrm{~m}$ depth) tailings, sampled with distance down spigot beach

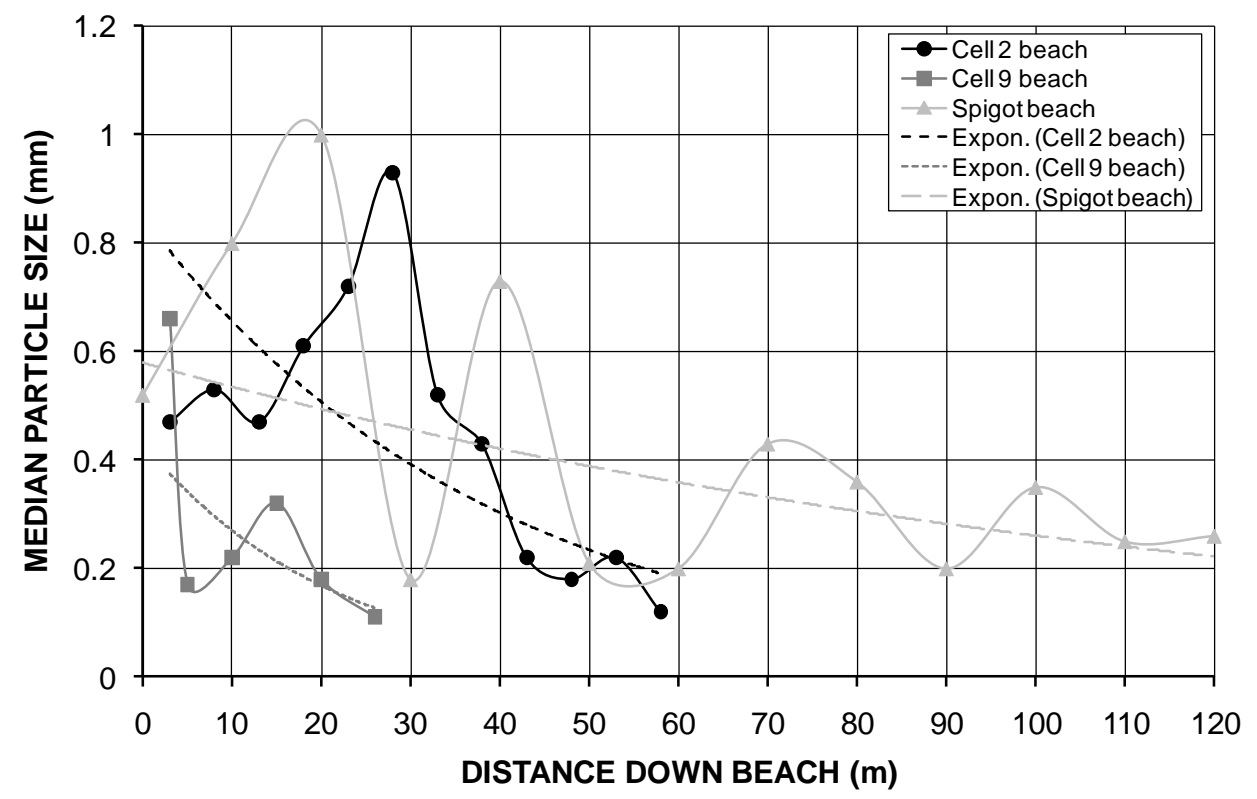

Figure 16 Median particle sizes of near-surface tailings $(0.033 \mathrm{~m}$ depth), sampled with distance down trial beaches

\section{Conclusions}

Given the coarse-grained nature of the East Weipa bauxite tailings, none of the five potential flowability criteria initially identified (which would be expected to be relevant for typical finer-grained tailings derived from mineral processing) was relevant. Instead, their field moisture content, suction (indicating desiccation), and shear strength (as indicated using a field shear vane) were the best indicators of flowability.

Field observations showed that the East Weipa bauxite tailings clearly 'flow' on deposition at typically $30 \%$ solids by mass (or gravimetric moisture content of 233\%), as would be expected. The spigoting of the tailings leads both to the development of a beach and the erosion of previously-deposited, settled, drained and desiccated tailings. Although the East Weipa bauxite tailings are deposited as a slurry, their coarsegrained nature ensures that they rapidly settle and drain and that they rapidly desiccate once the spigot is 
turned off at the end of a deposition cycle. The coarser-grained upper beach drains within half a day, much faster than the slimes towards the pond, as would be expected. The erosion scarps formed in previouslydeposited tailings do not flow; rather they remain near-vertical. The upper beach is used as a source of borrow for raises of the TSF walls, and the borrow pit excavations remain dry and stable.

The results of the field shear vane testing showed that, within 2 days of the end of deposition, the unconstrained tailings beach has a shear strength profile with depth many times higher than the self-weight only profile of the tailings, to a distance of about $100 \mathrm{~m}$ down the beach. The East Weipa bauxite tailings were found to be flowable only if their shear strength is at or below their self-weight only strength. This situation was only observed at the closed end of the laterally-constrained Cell 9, which represents a worst case, forcing the capture of fines and restricting the drainage of the beach, which would not occur in practice. The results obtained in the field were supported by laboratory testing, including moisture content determinations, suction testing (which confirmed desiccation), and particle size distribution analyses.

The results of the investigations demonstrated that East Weipa bauxite tailings spigoted from the perimeter wall rapidly (within 2 days) settle, drain and desiccate, and hence become non-flowable, to a distance down the beach of about $100 \mathrm{~m}$. Within about 4 weeks, the tailings beach becomes trafficable to about $150 \mathrm{~m}$. Erosion scarps formed in settled, drained and desiccated tailings by subsequent spigoting will not flow. Only tailings towards and beneath the pond (under-self-weight-consolidated) will have a potential to flow.

The results of the investigations led to the following operational procedures for the cyclic deposition of East Weipa bauxite tailings spigoted from the perimeter wall: (i) limit the deposition depth of each cycle to a maximum of $300 \mathrm{~mm}$, and (ii) allow at least 4 weeks between deposition cycles to allow the layer to settle, drain and desiccate, prior to the next $300 \mathrm{~mm}$ thick layer being placed. This implies a maximum rate of rise of $4 \mathrm{~m} /$ year. The anticipated rates of bauxite tailings production at East Weipa of 2.5-4.5 Mt/year (which equates to $1.9-3.5 \mathrm{Mm}^{3} /$ year, assuming an average dry density of $1.3 \mathrm{~g} / \mathrm{cm}^{3}$ ), if spread evenly over only one of the three cells at one time, would amount to rates of rise of 1.5-2.9 m/year, providing factors of safety with respect to rate of rise of at least 2.1-1.4.

It is noted that the approach and results presented in this paper are specific to the East Weipa bauxite tailings, and the operation of the East Weipa TSF. While this approach has been accepted by the Queensland Department of Environment and Resource Management (DERM) for the East Weipa TSF, each new application would have to be determined as "fit for purpose" on a case by case basis.

\section{Acknowledgements}

Rio Tinto Alcan (RTA) are acknowledged for funding the work on which this paper is based and for allowing the results of the investigations to be published. RTA Weipa Staff facilitated the field trials. The bulk of the onsite testing was carried out by Glynn Price of Golder Associates Pty Ltd's Perth Office. The laboratory testing was carried out within the Golder Geomechanics Centre at The University of Queensland.

\section{References}

AS 1289, Methods of Testing Soils for Engineering Purposes, Standards Australia.

GHD (2009) Investigations of East Weipa Bauxite Tailings Storage Facility, Report to Rio Tinto Alcan.

Rico, M., Benito, G., Salgueiro, A.R., Herrero, A.D. and Pereira, H.G. (2008) Reported tailings dam failures - A review of the European Incidents in the worldwide context, Journal of Hazardous Materials, Vol. 152, pp. 846-852.

Sammarco, O. (2006) Impacts of tailings flow slides, Mine Water and Environment, Vol. 18, No. 1, pp. 75-80.

Swarbrick, G.E. and Fell, R. (1992) Modelling desiccating behaviour of mine tailings, ASCE Journal of Geotechnical Engineering, Vol. 118, No. 4, pp. 540-557.

UNEP and ICOLD (2001) Tailings Dams, Risks of Dangerous Occurrences, Lessons Learnt from Practical Experiences, Bulletin No. 121. 
